\title{
Cyclic AMP-Responsive Element-Binding Protein 3-Like Protein 2
}

National Cancer Institute

\section{Source}

National Cancer Institute. Cyclic AMP-Responsive Element-Binding Protein 3-Like Protein

2. NCl Thesaurus. Code C95482.

Cyclic AMP-responsive element-binding protein 3-like protein 2 (520 aa, $257 \mathrm{kDa}$ ) is encoded by the human CREB3L2 gene. This protein is involved in the mediation of gene expression. 